\title{
Hiperrealitas Makna Bahagia Perempuan Karir Generasi Millennial Abad
}

\section{Erik Ardiyanto ${ }^{1^{*}}$}

${ }^{1}$ Program Studi Ilmu Komunikasi, Fakultas Falsafah dan Peradaban, Universitas Paramadina, Jl. Gatot Subroto, Kav. 97, Mampang, Jakarta, 12790

*Email Korespondensi: ardiyantoerik@gmail.com

Kata kunci: Hyperrealitas, Makna Bahagia, Perempuan Karier Abad 21

Keyword: Hyperrealitas Happy

Career Wowan $21 \mathrm{Era}$

\section{A B S T R A K}

Revolusi Industri 4.0 menciptakan sebuah paradigma baru yang sering disebut internet of things. Perubahan pardigma berpikir yang besar ini sangat mempengaruhi sistem dunia kerja saat ini. Perubahan ini tidak lain karena adanya otomasi disrupsi dalam bidang pekerjaan khususnya perempuan. Selain itu, konsep kolaborasi yang ditawarkan revolusi industri kali ini justru melanggengkan hegemoni sistem kapitalisme itu sendiri. Dalam hal ini sangat merugikan perempuan. Konsep kebahagiaan perempuan karier di abad 21 adalah buah hasil dari konstruksi perkembangan teknologi informasi dan komunikasi. Efek budaya modern kontemporer sangat nyata dalam menggubah perilaku perempuan karier hari ini dalam memaknai sebuah pekerjaan. Dalam bentuk pekerjaan modern seperti sekarang yang dianggap maju oleh sebagian kalangan, justru dalam praktiknya masih melanggengkan sistem patriarki yang selama ini ditentang oleh perempuan karir. Serta masih banyak bentuk ketidakailan gender dalam pekerjaan khususnya bagi perempuan karir hari ini. Di sisi lain, ada juga semacam gagap budaya Barat antara wanita karier di sektor formal, informal, pendatang, atau yang dari Jakarta. Namun dengan seiring berjalanya waktu dan perkembangan zaman seperti sekarang ini, yang menjadi perhatian sekaligus catatan dalam penelitian kali ini. Ketika semua pekerjaan nantinya sudah terotomasi semua dengan segala kemudahanya. Apakah makna bahagia dalam karier itu akan menjadi "Hyperrealitas" karena dalam penelitian ini, peneliti juga mendapati bahwa sudah ada teknologi "Editing Genome" yang bisa merancang suatu kebahagian.

\section{A B S T R A C T}

The Industrial Revolution 4.0 created a new paradigm which is often called the internet of things. This big paradigm change of thinking greatly affects the current system of the world of work. This change is none other than due to the automatic distribution in the field of work, especially women. In addition, the concept of collaboration offered by the industrial revolution this time actually perpetuates the hegemony of the capitalism system itself. In this case it is very detrimental to women. The concept of happiness for career women in the 21 st century is the result of the construction of the development of information and communication technology. The effect of modern contemporary culture is very real in changing the behavior of career women today in interpreting a job. In the form of modern work as it is now considered advanced by some circles, it is true that in practice it still perpetuates the patriarchal system which has been opposed by career women. And there are still many forms of gender irregularities in work, especially for career women today. On the other hand, there is also a kind of Western cultural stuttering between career women in the formal, informal sector, migrants, or those from Jakarta. However, with the passage of time and the times as it is today, it is a concern as well as a note in this research. When all the work will be automated, everything is easy. whether the meaning of being happy in that career will be "Hyperreality" because in this research, researcher also found that there is already "Genome Editing" technology that can design happiness

\section{PENDAHULUAN}

Kita sekarang memasuki hidup dalam abad 21. Pada abad ini ditandai dengan istilah yang kita kenal dengan Revolusi Industri 4.0. Pada sejarah awal revolusi industri pertama, muncul ditandai oleh penemuan (mesin uap), revolusi industri kedua, muncul ditandai dengan penemuan lampu (elektronik) dan revolusi industri ketiga, muncul ditandai dengan penemuan (mesin komputer). Namun, revolusi industri 4.0 kali ini sangatlah berbeda dengan revolusi industri sebelumnya khusus nya dari segi dampak dalam kaitan dengan relasi suatu pekerjaan. Revolusi kali ini 
memunculkan disruptions teknologi yang menuntut otomasi dalam hal pekerjaan. Dengan munculnya beberapa platform daring yang membuka lapangan pekerjaan yang baru disamping itu juga mengerus dan menyeleksi pekerjaan-pekerjaan lama. Revolusi kali ini dikenal dengan istilah era IoT (Internet of Thing).

Istilah modernisasi merupakan suatu proses perubahan masyarakat dari tradisional menjadi modern. Proses tersebut mengharuskan adanya penyesuaian sikap, untuk meninggalkan cara-cara terdahulu yang tidak sesuai dengan keadaan sekarang. Pasca awal revolusi industri kita melihat bahwa ada suatu pola perubahan yang sangat besar pada sektor pekerjaan buruh industri. Misalnya, pada sektor produksi yang awalnya diisi oleh sumber daya manusia dalam jumlah besar. Kemudian harus berkurang dan diganti oleh mesin-mesin yang mengakibatkan pengganguran besar-besaran ada di mana-mana karena perkejaan manusia terganti oleh mesin. Begitupun di sektor pekerjaan wanita yang sudah dari sejak lama terkena imbas dari relasi kuasa patriarki. Dengan pekerjaan yang di dominasi pasar laki-laki dengan adanya perubahan tersebut, peluang perempuan tentunya semakin menyusut.

Karl Marx (Engels, 2007) melihat masyarakat modern sangat berironi dengan kapitalisme. Menurutnya, modernisasi telah melemahkan tradisi dan budaya masyarakat. Selain itu, kapitalisme juga telah menigkatkan the division of labour yang membutuhkan sistem pembagian kerja yang spesifik supaya lebih efisien. Dengan kata lain, supaya kaum borjuis (penguasa modal) mendapatkan keuntungan yang berlipat. Oleh karena itu, Marx berpandangan modernisasi merupakan sebuah perjalanan yang menyengsarakan masyarakat, karena telah menghancurkan kebebasan, membelenggu kreativitas, dan memicu konflik sosial. Itulah sisi gelap modernisme yang bertemu dengan kapitalisme yang memang hanya memiliki satu tujuan, yaitu persoalan keuntungan semata pada pemodal. Menurut peneliti, kapitalisme menghasilkan relasi kuasa antara kelas pekerja dan pemodal yang terus mengalami pertentangan. Lebih spesifik hingga berimbas pada kelanggengan sistem patriarki dominasi laki-laki terhadap perempuan dalam sektor pekerjaaan. Sehingga, dalam hal ini membentuk sebuah alienasi dan sebuah kesadaran palsu (false consciousness) dalam karier perempuan. Wanita menjadi the other (liyan) dalam sistem kapitalisme.
Kemudian kemajuan kolaborasi antara ilmu pengetahuan dan teknologi dalam masyarakat modern. Hanya menjadikan terkikisnya sisi humanisme, terutama yang berkenaan dengan masalah perempuan, berada pada titik yang memprihatinkan. Jean Baudrillard (Lubis, 2014) pernah menyoroti dengan kritiknya yang sangat tajam terhadap sistem kapitalisme. Menurutnya, penyatuan antara konsep kebahagiaan dengan barang-barang produksi dalam era budaya populer dan kapitalisme sebenarnya merupakan bentuk dari hyperrealitas dalam karier, yaitu hilangnya ambang batas antara dunia nyata dan virtual yang sengaja dikonstruksi (simulasi) oleh para pemegang alat-alat produksi atau pemodal. Hal inilah yang menjadi kecurigaan peneliti bahwa dengan adanya narasi Revolusi Industri 4.0 justru akan semakin melenggengkan ketidakadilan gender itu sendiri dalam sistem kerja, khususnya bagi perempuan. Karena agenda dari kapitalisme itu sendiri yang selalu dibenarkan oleh science, kuasa, dan power. Karena, faktanya perangkat instrumen teknlogi dan informasi itu sendiri sampai saat ini masih digengam oleh kapitalisme dan dibalik itu justru menambah memarjinalisasi perempuan dalam karier.

Kemudian lewat kritik tajam ditandai dengan era baru, yaitu post-modernisme yang menandakan perubahan budaya, mulai dari gaya hidup hingga pardigma berpikir yang terjadi akibat perkembangan ilmu pengetahuan dan teknologi informasi. Konsekuensi atas hadirnya post-modernisme, yakni salah satunya paradigma modern tidak cukup relevan untuk memahami dan menjelaskan kebudayaan yang tengah tumbuh. Karena itu, berbagai kritik terhadap aspek-aspek kebudayaan dan paradigma modern bermunculan yang kemudian disebut degan post-modernisme. Kajian ini sangat memengaruhi relasi gender dalam ruang lingkup suatu pekerjaan terutama untuk perempuan.

Sejalan dengan itu, munculnya sebuah konsep jalan baru bagi gerakan perempuan dalam sektor pekerjaan, yaitu "post-feminisme" yang merupakan upaya sebagian perempuan untuk melakukan kritik dan otokritik dari dalam dan luar gerakan feminisme yang memberikan "suara lain" bagi gerakan perempuan. Tujuannya untuk memperbaiki kehidupan, baik dalam lingkungan kerja maupun keluarga, di dunia pemikiran ataupun di dunia aktivisme, di lingkungan real atau simbolik dan dunia sosial maupun dunia media. Dalam keinginan untuk mengkritisi isu-isu yang selama ini sering diangap bertentangan di 
kalangan feminis, misalnya dunia privat dan dunia pubik, atau keluarga dan karier. Kesadaran postfeminisme justru mencuatkan keyakinan di kalangan perempuan untuk memadukan dua dunia ini dalam arti penting peran laki-laki dalam kehidupan keluarga. Contoh sebagai "Bapak Rumah Tangga" bukan hanya perempuan sebagai "Ibu Rumah Tangga", dan karier seorang perempuan tidak mesti menegaskan nalurinya untuk membangun keluarga pada level kesadaran dan tingkatan individu.

Misalnya, banyak feminisme yang menduduki jabatan pemerintahan, organisasi pelayanan sosial, lembaga kajian wanita atau program-program akademis lainnya. Ini memungkinkan mereka untuk memadukan tujuantujuan politik ke dalam pekerjaan mereka dengan meneruskan untuk memilih waktu luang, relasi yang penting, dan busana serta penampilan diri yang konsisten dengan ideologi feminisme. Kesadaran dan kehidupan wanita yang tidak mengidentifikasi diri sebagai feminis pun telah berubah karena gerakan perempuan.

Dewasa ini, kesadaran akan kesetaraan gender semakin meningkat. Secara struktural dan fungsional, masyarakat dalam budaya postmodernisme telah membawa wanita mendobrak budaya-budaya konservatif. Wanita telah banyak merambah kehidupan publik yang selama ini didominasi pria. Wanita telah banyak bekerja di luar rumah dan banyak di antara mereka menjadi wanita karier. Istilah "karier" atau career (bahasa Inggris) berarti "A job or Profesion for which one is trained and which one intends to follow for part or whole of one's life. Atau "a Job or profession especially one withopportunittes for progress". Sementara "wanita karier" berarti wanita yang berkecimpung dalam kegiatan profesi seperti bidang usaha, perkantoran dan bahkan sudah merambah ke ranah politik yang dilandasi pendidikan keahlian.

Pekerjaan karier tidak sekadar bekerja, bisa merupakan ketertarikan seseorang pada suatu pekerjaan yang dilaksanakan atau ditekuni dalam waktu panjang (lama) secara penuh (fulltime) demi mencapai prestasi tinggi, baik dalam upah maupun status. Adapun yang lebih menekankan pada passion dalam bekarier bisa di dunia formal ataupun informal seperti kerja kantor corporate, entertainment, industri kreatif, dan dunia aktivisme sosial. Dengan demikian "wanita karier" adalah wanita yang menekuni dan mencintai sesuatu atau beberapa pekerjan secara penuh dalam waktu relatif lama, untuk mencapai suatu kemajuan hidup, pekerjaan atau jabatan. Umumnya, karier ditempuh oleh wanita di luar rumah sehingga wanita karier tergolong yang berkiprah di sektor publik. Di samping itu, untuk berkarier harus menekuni profesi tertentu yang membutuhkan kemampuan, kapasitas, dan keahlian dan acap kali hanya bisa diraih dengan persyaratan telah menempuh pendidikan tertentu.

Badan Pusat Statistik (2017) mengeluarkan rilis survei Indeks Kebahagian. Penduduk yang memiliki pendidikan tinggi ditemukan memiliki tingkat kebahagiaan lebih tinggi. Begitu pun dengan penduduk yang lajang mempunyai kebahagiaan lebih tinggi dari pada yang sudah menikah.

Secara umum, terindikasi bahwa semakin tinggi pendidikan penduduk Indonesia, maka semakin tinggi pula Indeks Kebahagiaan yang dimiliki. Pola yang sejalan juga terlihat pada ketiga dimensi penyusun indeks kebahagiaan, yaitu indeks dimensi kepuasan hidup, indeks dimensi perasaan, dan indeks makna hidup. Tingginya tingkat kebahagiaan penduduk yang memiliki tingkat pendidikan yang tinggi tersebut. Kemungkinan terjadi sebagai dampak dari luasnya pengetahuan penduduk yang berpengaruh pada peningkatan kualitas berbagai aspek kehidupan. Indeks penduduk dengan pendidikan S3/S2 (83,14\%), S1/Diploma IV (79,58\%), Diploma I, II, III $(78,23 \%)$, SMA Sederajat $(74,83 \%)$ SMP Sedrajat $(72,30 \%)$, SD Sederajat $(72,23)$, dan tidak tamat SD/Sederajat $(68,39 \%)$.

Menurut data Badan Pusat Statistik (2017), indeks kebahagiaan penduduk yang belum menikah cenderung lebih tinggi sebanyak $71,53 \%$ dibandingkan dengan penduduk dengan status perkawinan. Sementara untuk penduduk dengan status menikah memiliki indeks kebahagian $71,09 \%$, penduduk dengan status cerai hidup memiliki indeks kebahagiaan $67,83 \%$, dan penduduk dengan status cerai mati memiliki indeks kebahagiaan $68,37 \%$.

Namun ke depan setelah melawati beberapa fase di atas mulai dari revolusi industri, modernisasi, post-modernisme dan ditandai oleh gerakan post-feminisme dengan perubahan cara berpikir oleh wanita dalam memandang karier di era revolusi industri 4.0 dengan otomasi dalam pekerjaan. Tentu yang akan menjadi pertanyaan ke depan adalah bagaimana makna bahagia terutama dalam karier.

Setelah semua tercapai, Harari (2017) mengatakan bahwa proyek besar kedua pada agenda manusia adalah menemukan kunci makna 
arti sesungguhnya kebahagiaan. Sepanjang sejarah, banyak pemikir, nabi dan orang biasa mendefinisikan kebahagiaan bukan kehidupan itu sendiri sebagai kebaikan tertinggi. Dalam Yunani Kuno, filsuf Epicurus menjelaskan bahwa menyembah Tuhan itu membuang waktu, tidak ada eksistensi setelah kematian, dan kebahagian adalah tujuan tunggal kehidupan. Sejalan dengan berbagai padangan tentang arti dari sebuah "kebahagiaan" yang sampai sekarang masih menjadi perdebatan di kalangan akademisi dan masyarakat. Sementara sains bioteknologi telah menemukan bentuk rekayasa genetika adalah "editing genome". Kemudian timbul pertanyaan, apakah kebahagiaan khususnya dalam karier wanita ke depan adalah suatu bentuk konstruksi (simulasi), dalam ini hanya seperangkat alat ideologi kapitalisme untuk melanggengkan kekuasaannya.

Dari beberapa penjelasan di atas, maka peneliti tertarik untuk melakukan penelitian tentang "Hyperrealitas makna bahagia pada wanita karier generasi milenial yang belum menikah di kota Jakarta".

\section{Makna Bahagia}

Definisi kebahagiaan menurut Aristoteles bahwa happiness atau kebahagian berasal dari kata "happy" atau bahagia yang berarti feeling good, having fun, having a good time, atau sesuatu yang membuat pengalaman menyenangkan. Bagi Epicurus, pencarian kebahagiaan adalah pencarian personal. Sebaliknya, para pemikir modern cenderung melihatnya sebagai proyek kolektif. Tanpa perencanaan pemerintah, sumber daya ekonomi, dan saintifik, individu-individu tidak akan bisa jauh melangkah dalam mencari kebahagiaan. Jika negara dipecah oleh perang, jika ekonomi terserang krisis, dan perawatan kesehatan tidak ada, tentu ini menimbulkan penderitaan.

Pada abad ke-18, filsuf Inggris Jeremy Bentham menyatakan bahwa kebaikan tertinggi adalah "kebahagiaan terhebat bagi banyak anggota" dan menyimpulkan bahwa tujuan tunggal negara, pasar, dan komunitas saintifik adalah meningkatkan kebahagian global. Para politisi harus menciptakan perdamaian, orangorang bisnis harus memperkuat kemakmuran, dan para sarjana harus mempelajari alam, bukan demi kejayaan raja, negara atau Tuhan, melainkan agar dapat menikmati kehidupan yang lebih bahagia.
Dalam abad ke-19 dan ke-20, Harari (2018) mengatakan pemerintah, korporasi, dan laboratorium fokus pada tujuan-tujuan yang lebih langsung dan lebih jelas pendefinisiannya. Negara-negara mengukur keberhasilan dengan teritori, kenaikan populasi, dan pertumbuhan GDP bukan dengan kebahagiaan warganya. Namun, pada abad ke-20, GDP mungkin menjadi tolak ukur tertinggi untuk mengevaluasi keberhasilan bangsa. Dari prespektif ini muncul pengganti dengan GDH (Gross Domestic Happiness) jadi apa sesungguhnya yang diinginkan orang, mereka tidak ingin memproduksi, tetapi mereka ingin bahagia. Produksi menjadi penting karena basis material bagi kebahagiaan. Namun, itu hanya sarana, bukan tujuan.

Jenis logika inilah yang medorong manusia menjadikan kebahgian sebagai tujuan utama abad ke-21. Acap kebahagiaan mampu bertahan sering ditopang oleh dua pilar kokoh, yakni psikologi dan biologi. Pada level psikologi, kebahagiaan tergantung pada ekspektasi, bukan kondisikondisi objektif. Sedangkan pada level biologis, kebahagian ditentukan oleh biokimia, bukan situasi ekomoni, sosial, dan politik.

\section{Ekstasi Komunikasi}

Hampir semua karya Baudrillard selalu membicarakan soal "objek". Perhatian dilandasi atas keresahan dan kritiknya pada teori ekonomi yang dikembangkan Marx. Utamanya yang berhubungan dengan nilai guna dan arena telah terjadi pergeseran dalam memaknai nilai guna suatu objek, maka Baudrillard mengembangkan kritiknya ke arah teori produksi dan objek.

Baudrillard (2006) memiliki sesuatu yang menarik tentang bahasa dan makna. Pembahasannya tentang objek yang semula berdasarkan teori ekonomi positif berubah menjadi ekonomi adiktif. Ekonomi adiktif adalah sebuah prinsip di mana orang lebih suka dan cenderung mencandu dalam mengonsumsi daripada menjadi memproduksi. Jika dibayangkan lebih jauh, maka orang demikian sudah mulai dihilangkan sarana ide-ide dan kreativitasnya, proses itu semua telah diambil oleh sebuah kekuatan besar yang diam-diam memaksakan kehendaknya melalui saran dan hasil produksi.

Segala sesuatu di mulai dari objek, namun tidak ada lagi sistem objek. Kritik terhadap objek didasarkan atas tanda yang mengandung makna di samping fantasi dan logika bawah sadar maupun logika diferensialnya yang prestisius. Di balik logika ganda tersimpan mimpi antropologis 
tentang objek yang berada di luar dan di atas pertukaran dan kegunaan, di atas dan di luar kesamaan tentang logika pengorbanan, pemberian hadiah, pengeluran, potlatch, konsumsi tumbal (devil a share) dan pertukaran simbolik. Semua itu masih berlangsung sampai sekarang, namun perlahan-lahan mulai menghilang. Deskripsi imajinasi proyektif imajiner dan semesta simbolik masih menjadi objek yang merupakan cerminan subjek. Oposisi subjek dan objek masih signifikan seperti cermin dan bayangan. Peristiwa sejarah sebagaimana peristiwa sehari-hari muncul sebagai bayangan dari sejarah yang makin terlepas dari politik. Sekarang bayangkan kaca telah runtuh ke arah layar raksasa dan jaringan. Tidak terdapat transedensi atau ke dalamannya, yang ada hanya operasi tanpa ujung permukaan komunikasi licin dan fungsional. Dalam citra televisi, prototype objek paling indah abad ke-21, dunia sekitar dan tubuh kita sendiri menjadi layar yang dapat ditonton.

Kita tidak mengarahkan emosi-emosi yang sama seperti dulu kepada objek. Mimpi-mimpi yang sama tentang rasa memiliki, rasa kehilangan, duka-cita ataupun kecemburuan. Dimensi psikologis menjadi kabur meskipun seseorang mampu meraihnya kembali dalam hal-hal tertentu. Sampai dengan satelitasi riil itu sendiri, habitat kehidupan sehari-hari yang telah terhipotasi menandakan berakhirnya metafisika dan alamat dimulainya era hyperrealitas. Era sebelumya hanya diproyeksi secara mental, yang dihayati sebagai metafora dalam keseharian, namun mulai sekarang diproyeksikan ke dalam ruang simulasi absolute dan itu tanpa metafora sama sekali.

Ruang privat tidak lagi menjadi panggung di mana drama tentang subjek yang berhadaphadapan dengan objek dan citranya sendiri dimainkan. Termasuk proses kerja, berada dalam prospek kerja telematik yang dilakukan di rumah, begitu juga dengan konsumsi, permainan di rumah, hubungan-hubungan sosial, dan waktu luang, kita dapat membayangkan simulasi situasi senggang atau liburan sama dengan simulasi terbang para pilot.

Apakah semua ini adalah bentuk fiksi ilmiah karena sampai sekarang seluruh mutasi lingkungan berasal dari kecenderungan yang mengarah pada abstraksi formal terhadap unsurunsur dan fungsi-fungsi, pada homogenisasi mereka pada proses tunggal juga pada kebiasaankebiasaan gestural baik tubuh atau tindakan elektrik maupun elektronik, cendrung diminiatur dalam ruang waktu. Inilah masalah kita, selama gegar otak akibat elektronik ini, miniaturisasi proses kerja dan tenaga ini, transistorasi lingkungan ini dikambinghitakamkan karena kesia-siaan seketika membentuk panggung kehidupan kita.

Mikro proses atas waktu, tubuh dan kenikmatan telah datang tidak terdapat lagi prinsip ideal tentang hal-hal itu menuntut standar manusia. Yang tersisa kemudian adalah dampakdampak yang terminiaturisasi, terpusat dan berdampak secara langsung. Perubahan standar ini dapat dilihat diaman tubuh manusia, tubuh kita sendiri membludak dan melewer, dalam kompleksitas dan ragam organ, otot dan fungsinya karena di masa sekarang organ, otot dan fungsinya karena di masa sekarang segalanya dipusatkan di otak dan kode genetik sebagai sampul terakhir definisi keberadaan operasional keberadaan (being). Lanskap geografis terlihat lebih luas, dia menjadi tubuh mandul dan mahal yang luas tidak lagi penting seperti menyebrang jalan tol yang membosankan, semenjak semua kegiatan terpusat di perkotaan, yang juga direduksi ke beberapa gedung-gedung pencakar langit yang terminiaturisasi secara ekstrem. Panjangnya waktu mengelilingi kita bagai pantai yang kosong. Bagaimana dengan perluasan yang hanya melahirkan kehampaan makna yang terungkap ketika komunikasi dadakan meminiaturkan pertukaran menjadi sebatas rangkaian hal-hal yang instan. Tubuh sebagai panggung, lanskap seabagai panggung dan waktu sebagai sebuah panggung perlahan-lahan mulai menghilang. Hal yang sama juga terjadi pada ruang publik. Teater sosial dan tubuh tak berupa dan berlipat ganda. Periklanan terbarunya bukan lagi seperti di zaman barok, sekenario utopis yang mabuk kepayang akibat objek dan konsumsi.

Ruang privat juga mengalami nasib yang sama. Ia menghilang bersamaan dengan lenyapnya ruang publik. Keduanya tidak lagi jadi tontonan atau rahasia. Ruang privat menjadi terasing, sepanjang ia terpisah satu sama lainya, dari dunia yang di dalamnya ruang privat diperlukan sebagai wilayah yang dilindungi. Dunia sebagai pelindung imajiner. Namun ruang privat juga berisi keuntungan simbolis keterasingan kenyataan bahwa pihak lain masih ada dan kelainan itu bisa jadi menguntungkan atau merugikan.

Jadi, masyarakat konsumen hidup di bawah tanda keterasingan. Masyarakat konsumen adalah masyarakat tontonan tidak pernah cabul. Kecabulan dimulai ketika tidak ada totonan, tidak 
ada lagi panggung, teater, ilusi, ketika segala sesuatu tembus padang, dapat dilihat, diekspos dalam informasi dan komunikasi yang mentah dan tidak dapat dielakan. Ketika tidak lagi berperan dalam drama keterasingan tapi dalam ektasi komunikasi. Dan ekstasi yang demikian itu cabul. Kecabulan adalah sesuatu yang menghapuskan pandangan, citra, dan semua bentuk representasi.

\section{Hiperalitas - Jean Baudrilard}

Munculnya era baru (post-modernisme) dalam perkembangan ilmu pengetahuan ditandai dengan semakin mapannya kapitalisme, penyebaran teknologi dan informasi secara masif, semakin dahsyatnya konsumerisme, dan munculnya sebuah kebudayaan baru disebut dunia hiperealitas.

Hiperealitas secara harafiah berarti sebuah realitas yang berlebihan meledak dan semu. Istilah ini digunakan Jean Baudrillard sebagai pengambaran terhadap suatu kondisi tersebut sedang dialami oleh masyarakat dewasa ini yang mengikuti laju perkembangan sains dan teknologi informasi yang tidak terbendung.

Baudrillad mengarahkan perhatiannya pada analisis tentang masyarakat kontemporer, yang dalam pandangannya, tidak lagi didominasi oleh produksi, tetapi lebih tepatnya oleh media, model sibernetik (bersifat dunia maya) dan sistem pengendalian, komputer, pemrosesan informasi, dunia hiburan dan industri pengetahuan dan sebagainya. Sedikit berbeda dengan sosiolog postmodern lainnya yang terfokus pada kajian metafisis.

Konsep hiperealitas sendiri perhatiannya pada kecenderungan masyarakat melepaskan batas-batas dalam memahami sebuah "kenyataan" yang didasari pengalaman dengan "kenyataan" yang sengaja diciptakan melalui model konseptual atau yang Baudrillard sebut sebagai simulation. Proses simulasi mengarah pada penciptaan simulacra (simulacra) atau reproduksi obyek atau peristiwa. Maksudnya, penciptaan ulang sebuah kejadian atau peristiwa sebelum peristiwa itu benar-benar (akan) terjadi dan ada di dunia nyata secara terus-menerus. Contohnya pada film fiksi yang tiada hentinya ditayangkan, dan jelas bahwa peristiwa dalam film tersebut yang tiada hentinya ditanyangkan, dan jelas bahwa peristiwa dalam film tersebut tidak betul-betul ada dan terjadi di dunia nyata. Maka demikian disebut sebagai simulasi, yaitu kenyataan yang dibuat tanpa referensi dan bersifat tipuan. Proses tersebut muncul beriringan dengan pesatnya perkembangan teknologi di era digital. Simulacra yang berarti tanda atau kode, masuk dan mendominasi kehidupan masyarakat melebihi dominasi unsur kehidupan nyata. Pada akhirnya, hiperealitas menjadi kesimpulan terhadap sulitnya membedakan antara realitas yang nyata dengan realitas yang tidak nyata (semu), atau anggapan bahwa realitas semu lebih nyata daripada kenyataan yang sebenarnya.

Dalam dunia simulasi sulit dibedakan batas-batas antara imajinasi dan realitas, keduanya menjadi setara karena posisi imajinasi berada dalam realitas nyata dapat dibedakan antara yang benar dengan yang salah, antara yang nyata dan yang imajiner maka simulasi meluruhan kedua kutub perbedaan. Kutub realitas dan kutub imajiner luruh dalam ruang simukarum. Dalam tataran kesadaran, simulasi menutup kesadaran seseorang akan realitas yang sesungguhnya. Logika yang berlaku dalam simulasi sama sekali tidak berhubungan dengan logika realitas yang sesungguhnya.

Konsep karier wanita modern abad 21 ini yang kita sebut sebagai sub-culture postfeminisme juga telah mengalami pergeseran. Pengaruh media sosial dan teknologi sangat kental dalam konsep wanita karier hari ini. Karier tidak lagi dimaknai untuk pemuasan passion dalam bekerja atau pencarian nafkah. Namun karir juga dipandang sebagai gaya hidup (lifestyle) masyarakat modern (kontemporer). Sehingga kemudian banyak menimbulkan pertanyaan terhadap apa makna bahagia bagi wanita karier khususnya generasi milenial. Privilege sebagian wanita-wanita berparas cantik dalam memperoleh karier hanya dengan mengadalkan wajah. Bentuk dari budaya kontemporer yang sangat memengaruhi cara pandang wanita karier ataukah ada motif lain yang menyangkut wilayah-wilayah privat dan ideologi sehingga konsep karier hari ini sangat hyperrealitas seperti yang dikatakan Jean Baudrillard.

\section{Post-Feminisme}

Saat ini menjadi salah satu terminologi yang cukup popular dalam wacana-wacana era pasca modern (post-modern). Sebagai satu varian ideologi post-modernisme, tentu gerakan dan ideologi post-feminisme juga mengusung ide-ide yang ada dalam wacana post-modern. Boleh dikatakan bahwa gerakan post-feminis adalah perkawinan antara gerakan kesadaran gender yang dibingkai dengan prespektif post-modernisme. Post-feminisme juga banyak disebut sebagai 
gerakan gelombang ketiga di mana permainan wacana (discourse) menjadi salah satu bagian penting dari strategi gerakan.

Meiliana (2016) mengatakan postfeminisme sering dikaitkan dengan era pasca 1990. Pada masa ini, post-feminisme dipopulerkan melalui diskursus media popular. Pandangan post-feminisme tidak muncul dari suatu aksi revolusioner atau momental, melainkan melalui pengenalan istilah dari media. Secara terminologi, post-feminisme muncul pada kisaran 1982 yang diinisiasi oleh pemberitaan media.

Secara umum argumen utama dalam postfeminisme adalah struktur organisasi pergerakan yang menggunakan label feminisme terbukti tidak efektif. Permasalahan-permasalahan mengenai perempuan tidak menemui solusi yang sangat signifikan dalam perkembangan protes feminisme. Berangkat dari klaim terhadap kegagalan feminisme, post-feminisme muncul menawarkan argumen yang berbeda dari feminisme. Bahwa perempuan tidak harus berada diluar struktur yang patriarki yang melakukan perlawanan, melainkan bergerak naik dalam sistem yang operasif disebut sebagai celebratory and optimistic movement (Walter, 1999).

Post-feminisme secara ideologis melihat bahwa pergerakan perempuan tidak seharusnya destruktif dengan menggunakan pergerakan politik, melainkan dengan memanfaatkan nature kewanitaan yang dibayangkan sebagai sifat-sifat lembut yang dimiliki perempuan. Dalam pemahaman Showden (2009) disampaikan bahwa "women abuse the power that comes with these sugar and spice and all that's nice" yang memperlihatkan secara ideologis pergerakan perempuan yang destruktif tidak menjadi poin utama dalam post-feminisme, karena hal tersebut dipandang menegasikan nature perempuan yang lembut.

Secara ideologis pandangan post-feminisme juga menolak adanya tujuan-tujuan pembebasan perempuan seperti yang disampaikan Bollotin (1982) yaitu, the battle for equality has been won, and it is time to stop "harping" on women's oppression. Pernyataan Bollotin mengindikasikan bahwa post-feminisme bertujuan untuk melakukan politik pembebasan terhadap perempuan dari struktur yang patriarki. Postfeminisme menganggap perjuangan pembebasan perempuan telah berakhir dan dimenangkan oleh identitas perempuan. Dalam konteks kekinian yang tersisa adalah perjuangan untuk melakukan ekspresi yang variatif dengan tetap diungkapkan
Wolf (Nguyen, 2013) bahwa "believes women deserve to feel that the qualities of starlets and queens, of sensuality and beauty, can be theirs."

Secara umum fokus utama dari postfeminisme adalah hendak mengatakan bahwa perjuangan yang dilakukan oleh feminisme telah usang. Kesetaraan telah dimenangkan dan perempuan harus melangkah lebih jauh.

\section{METODE PENELITIAN}

Penelitian ini mengunakan paradigma kritis sebagai acuan dalam pendekatan. Paradigma ini pada dasarnya adalah paradigma ilmu pengetahuan yang meletakan epistimologi kritik maxisme. Pengaruh gagasan marxisme dan teori kritis mempengaruhi filsafat pengetahuan paradigma kritis. Paradigma kritis memandang realitas yang ada adalah relaitas semu. Karena dipengaruhi oleh berbagai kekuatan ekonomi, politik, dan sosial. Teori kritis bertujuan mengungkap hakikat dan sifat masyarakat secara lebih aktual (Ritzer \& Goodman, 2007).

Tujuan dilakukan penelitian dengan paradigma kritis menurut Patton adalah untuk melakukan kritik terhadap kondisi masyarakat dengan cara mengungkap sejarah, meningkatkan kesadaran, dan berupaya untuk menyeimbangkan kekuasaan atar yang berkuasa dan yang dikuasai. Sementara itu, Neuman (2013) mengatakan bahwa tujuan dari penelitian kritis tidak semata untuk mengkaji dunia kritis dilakukan untuk menyibak mitos, mengungkap kebenaran yang tersembunyi dan membantu masyarakat untuk mengungkap kebenaran mereka sendiri, secara spesifik, kelompok yang tertindas oleh kelompok dominan.

Begitupun yang terjadi terhadap fenomena perempuan karier generasi milenial yang belum menikah di kota metropolitan Jakarta. Ada banyak bentuk ketidakadilan gender dalam karier wanita pekerja sektor formal atau non formal. Seperti bentuk relasi kuasa dalam struktur pekerjaan yang didominasi laki-laki. Bentuk baru alieanisasai dalam pekerjaan dalam konteks masyarakat kontemporer. Hingga kesadaran palsu yang dikonstruksi oleh budaya popular, serta gagap budaya pada sektor wanita karier asal daerah yang tinggal di Jakarta. Lalu, bagaimana dampak media sosial dalam mengkonstruksi konsep makna perempuan karier generasi millennial hari ini. Hal ini yang akan coba peneliti kupas secara mendalam baik secara aspek historis, lingkungan sosial, lingkungan keluarga, aspek budaya. 
Peneliti menaruh kecurigaan pada motif ideologi dominan yang sangat memengaruhi keputusankeputusan tersebut.

\section{HASIL DAN PEMBAHASAN}

Setelah melakukan wawancara dengan 10 narasumber wanita karier generasi milenial di Jakarta. Peneliti membagi menjadi dua bagian, yakni wanita karier pekerja di sektor formal dan informal. Adapun yang bekerja di sektor formal yaitu yang pertama adalah Desi yang bekerja di Hotel Shangrila Jakarta sebagai sales koordinator. Kedua, Wenny yang bekerja sebagai Pegawai Negeri Sipil (PNS). Ketiga, Kiren sebagai staf di Pengadilan Negeri Agama Jakarta Selatan. Keempat, Celi yang bekerja sebagai public relations di perusahaan periklanan. Keempat, Vina sebagai seorang dosen dan aktivis di Komnas Perempuan.

Kemudian yang bekerja di sektor nonformal. Pertama, Meyane seorang pekerja kreatif. Kedua, Lolita sebagai influencer dan selebgram. Ketiga, Anggi yang bekerja di bidang entertainment dan presenter. Keempat, Rina yang bekerja sebagai model. Kelima, Fiki seorang politisi muda dari Partai Garuda yang sekarang maju sebagai caleg DPR RI Dapil II DKI Jakarta.

Pada Meyane, konsep karier yang dibangun sangatlah berbeda dengan yang lainnya. Adapun faktor dari Meyane yang kategori wanita generasi milenial $\mathrm{Z}$ yang lahir sudah kenal dengan media sosial. Meyane tidak lagi mengenal status sosial dalam sebuah pekerjaan, yang mana ketika seorang Jakarta freshgraduate menginginkan kerja sebagai seorang PNS atau pekerja BUMN yang boleh dikatakan lebih aman untuk masa depan. Desakan dari orangtua untuk bekerja di sektor formal pun tidak dipedulikannya. Tapi Meyane lebih memilih bekerja sebagai seorang pekerja kreatif di bidang startup. Meskipun saat lulus kuliah Meyane sudah mendapatkan tawaran bekerja di kantor hukum sesuai dengan jurusan waktu kuliah. Justru, hari-hari Meyane sekarang dihabiskan bekerja di co-working space untuk promosi sebuah film. Dengan bekerja yang tidak terikat oleh waktu sehingga passion yang lain dan hobinya bisa tersalurkan seperti liburan dan bermusik. Meyane sangatlah bahagia dengan karier yang dijalani sekarang dengan pekerjaan yang tidak terikat. Stereotip tentang bekerja yang harus ke kantor tiap pagi jam 8 sampai dengan jam 5 sore baginya terlalu membosankan.

Meyane sangat familar dengan era revolusi industri 4.0 tentang dampaknya bagi pekerjaan.
Boleh dikatakan Meyane sudah sangat siap dengan segala bentuk otomasi dalam karier jika nantinya semua pekerjaan terganti oleh mesin Artificial Intellegent. Meyane seorang yang open mind, bahkan dia mengakui sebagai seorang libertarian (self proclaim). Apa yang dicitrakan di media sosial tentang dirinya terutama dalam karier dia tidak pernah mem-filter sedikitpun. Dia ingin mengekspresikan dirinya dengan penuh gairah dan passion. Pandangan sebagai seorang feminism libertarian ini sangat mempengaruhinya dalam hal karier dan makna bahagia dalam hidupnya. Namun kota Jakarta saat ini baginya belum bisa menjawab semua ekspektasinya, terutama karier. Dia ingin suatu saat nanti pindah ke luar negeri yang lebih bisa menjawab apa yang menjadi ekspektasinya dengan hidup bebas.

Lalu, pandangan Lolita tentang karier tentu sangatlah berbeda dengan yang lainnya. Pekerjaannya yang boleh dibilang pekerjaan yang baru muncul di abad 21 revolusi industri 4.0. Lolita sangat mantap menekuni karier sebagai seorang influencer dengan memanfaatkan media sosial seperti Instagram dan Twitter untuk mendapatkan penghasilan. Awalnya, sebagai influencer adalah sebuah ketidaksengajaan lebih tepatnya hobi yang kebetulan aktif di Twitter. Dia dikenal dengan kata-kata yang puitis oleh netizen di Twitter. Di Instagram, dia mencitrakan dirinya sebagai seorang yang aktif dalam kegiatan olahraga. Lewat personal branding di media, dia sering mendapatkan tawaran pekerjaan untuk promosi beberapa pakaian dan sponsor kegiatan running. Selain itu, juga dia direkrut oleh salah satu tim sukses kandidat presiden. Lewat kata dan kontennya dalam bermedia sosial, dia manfaatkan untuk membantu salah satu paslon presiden. Awalnya, di samping aktif di sosial media Lolita juga mempunyai sebuah pekerjaan di periklanan.

Kemudian dia berani untuk memutuskan keluar dari pekerjaan yang dulu di periklanan dan total sebagai influencer sekarang. Dia berpendapat bahwa kedepan akan ada beberapa pekerjaan baru yang akan muncul lewat sosial media. Tentunya jika kita bisa menangkap perkembangan perubahan dunia ke depan. Pengalaman bertemu orang-orang baru dan komunitas di dunia influncer yang sangat mempengaruhinya terutama dalam karier yang dijalani sampai sekarang.

Mandiri dan independen adalah kesan yang pertama saya dapatkan pertama kali ketemu Lolita. Dia adalah seorang yang sangat menikmati pekerjaannya. Baginya status sosial akan sebuah pekerjaan tidak terlalu penting yang terpenting 
baginya adalah pendapatan perbulan yang lumayan, dengan waktu senggang yang banyak. Lolita sangat familiar dengan feminisme dia sangat setuju dengan kesetaran dan nilai-nilai pemenuhan hak-hak komunal dalam masyarakat khusunya dalam karir. Sehingga wanita dalam karir bisa menentukan arah langkah kedepan tanpa pakasaan dalam system patriarki yang sudah berjalan sangat lama tegasnya. Kota Jakarta baginya kedepan harus ramah oleh perempuan untuk meniti karir dalam sektor apapun termasuk seperti sektor non formal yang dia tekuni seperti sekarang ini. Dia mencontohkan seperti luar negri sebagai rujukan untuk meniti kariri yaitu China. Walaupun untuk saat ini dia menambahakan bahwa Jakarta belum bisa menjawab semua expektasi yang diinginkanya terutama tentang karir yang sudah dicapainya. Sebagai anak tunggal memang dia tidak terlalu dibebani oleh banyak hal misalnya tanggung jawab terhadap adik-adiknya. Namun dengan pekerjaannya sekarang, dia bisa membantu orang tuanya. Begitu pun di usianya sekarang sudah mau menginjak 30-an tidak adanya paksaan dari orangtuanya untuk segera menikah. Dia lebih memilih tinggal sendiri di sebuah apartement di daerah Bintaro. Komunikasi yang dia bangun terhadap keluarga, teman sesama influencer, kolega dan fansnya pun terjalin dengan baik sampai hari ini.

Pada Anggi ang kesan yang saya dapat setelah melakukan wacara orangnya sangat struggle and presistene itu terlihat dengan beberapa pencapaian-pencapaian dalam karir. Anggi ang mengawali karir terjun kedunia entertainment dan jurnalis saat masih di semarang. Awalnya dia ditawari sebagai sebagai seorang peran pembantu di sebuah Film FTV dan bekerja sebagai presenter di Stasiun TV lokal di Semarang. Dia bercerita sejak dari SMP sudah jadi seoarang perantau sendiri karena ayahnya sebagai seorang TNI yang selalu pindah-pindah. Didikan dan terbiasa hidup sendiri tanpa orang tuan dari kecil itu yang membuat dia mandiri seperti sekarang ini. Titik baliknya dia menjadi sangat persistence dalam mencapai target-target dalam hidupnya adalah ketika waktu menjadi presenter pertama kalinya pernah dianggap sebelah mata oleh produsernya di Semarang. Ceritanya waktu itu ketika dia ingin mengajukan cuti libur, namun tidak diperbolehkan, malah si produser mengatakan: presenter seperti kamu ini mencari di jalan pun banyak. Setelah kejadian itu, kata - kata itu sangat membekas hingga har ini, kemudian setelah berpikir medalam jelang berapa minggu kemudian, dia memutuskan untuk keluar dari pekerjaannya itu.

Kemudian setelah lulus kuliah dia akhirnya memutuskan pergi meratau ke Jakarta dengan segenap harapan dan mimpinya. Dia kemudian menjadi presenter termuda NET TV pada usia 20 tahun. Tuntutan pekerjaan di media yang sangat sarat persaingan dengan pengalamanya yang masih awam saat pertama di Jakarta. Membuatnya ingin terus mengupdate tentang skill dan keampuanya. Sala satunya dengan mengejar kuliah S2 dengan mengambil komunikasi politik. Dia menjalankan kuliah dan pekerjaan sekaligus walupun dengan pressure yang tinggi. Dari situ karirnya mulai menanjak dengan beberapa program acara yang dipegangnya. Bahkan dia pernah diberi kesempatan untuk khusus meliput ahok dan mewancarainya dalam pilkada DKI. Tawaranpun pekerjaanpun tidak datang hanya di dunia jurnalisme berita. Beberapa kali didapuk sebagai pembawa acara untuk talk show comedy, jadi bintang iklan di beberapa produk kecantikan, main film FTV kejar tayang sampai terakhir dia main Film yang melabungkan namanya Susah Sinyal.

Pada akhinya dia sekarang memutuskan keluar di Net TV untuk lebih mantap secara total terjun di dunia Entertaiment dengan lebih menjual Anggi ang nya secara personal branding. Sekarang di mulai medapat kontrak dengan berbagai satsiun TV di Metro TV untuk program sanitasi negri dan presenter olahraga di berbagai stasiun televisi lainnya. Dalam waktu dekat ini, dia akan memutusakan untuk menekuni satu bidang khusus yang akan menjadi ciri khasnya kelak nanti. Namun tidak lepas dari dunia entertainment.

Persaingan yang sangat ketat di dunia entertainment memaksanya untuk terus menerus meningkatkan skiilnya. Karena ketika hanya bermodal paras cantik saja, setiap tahun pendatang baru selalu ada dengan tampilan yang lebih beda dan fresh. Ciri khas yang melekat menjadi penting dalam dunia yang dijalaninya sekarang ini. Upaya untuk terus menambah ilmu dilakukan dengan mengevaluasi segala bentuk pencapaiannya setiap tahun. Bahkan setiap acara ataupun kegiatan yang melibatkan dirinya, sehabis acara dia selalu minta masukan kepada produser tentang apa kekurangan dalam dirinya.

Dia meyadari bahwa dunia entertainment selalu melibatkan beberapa stakeholder. Strategi komunikasi yang di bangunya dengan beberapa pihak tekait dengan konsep yang mengedepakan 
pertemanan selepas bekerja. Dia tak segan untuk ikut bergabung dengan orang terkait untuk sekadar hangout ataukah bahkan sampai ke tempat clubbing. Ini penting dalam rangka membangun kemistri dalam sebuah pekerjaan baginya. Di tambah lagi dengan faktor otomasi seperti sekarang media-media mainstream yang sudah banyak ditinggalkan oleh kalangan muda yang lebih memilih media baru. Dia terlihat sudah sangat siap akan hal itu dengan mengelola sosial media yang dia milki. Dia sudah menyiakan konten-konten yang menarik untuk sosial medianya. Bahkan dia sudah menyiapakan media seperti youtube untuk aktuliasinya kelak jika orang sudah bener berpindah ke media alternatif. Personal branding di media yang dibangun adalah dia bahagia dalam hidup. Selama liburan apapun dan kegiatan kesehariannya yang dibagikan di media sosial selalu mencitrakan kebahagiaan. Meskipun sekarang dia baru putus dengan pacarnya dan pacarnya memutuskan untuk menikah dengan orang lain. Dia ingin menginspirasi semua followers-nya, khususnya fansnya untuk selalu hidup bahagia. Sesulit apapun dan seberat apapun masalahnya harus tetap bahagia.

Dia bercerita ada bentuk relasi kuasa antara seorang presenter ataukah seorang talend dengan produser atau sutradara dengan sangat terikat. Ini yang mau tidak mau dilakukan oleh beberapa orang yang terjun di dunia entertainment seperti yang baru pertama awal bahwa budaya patriakri juga masih sangat melekat dalam sektor dunia entertainment. Dengan petinggi atau produser media atau production house yang rata-rata masih di pengang oleh seorang laki-laki. Disini sangat tidak menguntungkan perempuan dalam hal karir khususnya di dunia entertainment. Banyak terjadi exlpoitasi bahkan pelecahan seksual yang sering ia jumpai seperti cat calling yang membuatnya kadang tidak nyaman. Tapi satu sisi berkarir di Jakarta dan menjadi seorang public figure adalah pilihan sekaligus impianya sejak lama. Jakarta baginya adalah jawaban atas mimpi-mimpinya sejak dulu ketika dia masih di Medan. Keputusan merantau ke Jakarta dinilai sangatlah tepat dalam kariernya.

Pencapaianya sekarang dari segi penghasilan boleh dibilang sudah cukup fantastis. Tidak hanya cukup untuk menghidupi dirinya, tapi juga sudah bisa membantu orangtuanya. Walapun dengan tekanan pekerajaan yang sangat tinggi dan tidak terikat. Dia sangatlah bahagia atas pencapaian-pencapaian yang diraihnya sekarang.
Dia bisa menentukan otoritas dirinya sesuai pilihan-pilihanya hari ini. Dia sangat setuju dengan konsep kesetaraan gender dan emansipasi wanita. Meskipun dia tidak menggangap dirinya sebagai sebuah feminis. Dia yang sedikit liberal, mengaku sangat cocok dengan beberapa pandagan tentang feminisme liberal dalam karier. Ada nilainilai yang menurutnya cocok dengan karakter dan konsidinya sekarang. Dia pribadi orang yang sangat menjujung tinggi kebebasan individu.

Pada narsum Kiren, tetang arti bahagia dalam karir adalah ketika apa yang ia cita-citakan untuk mempunyai kantor notaris tercapai. Kiren terlihat mempersiapkan karinya dengan matang sedari dini. Bahkan sekarang dia bekerja di kantor pengadilan agama Jakarta Selatan. Disitu dia bekerja untuk pengurusan kasus perceraian yang ada di Jakarta Selatan. Dia menemukan bahwa kasus perceraian yang terjadi di Kota Jakarta Selatan justrul rata-rata adalah pasangan muda yang baru menikah. Rata-rata problem yang dialami karena faktor financial yang kurang mapan. Hal ini lah yang melatarbelakanginya untuk tidak siap nikah muda, jika secara financial tidak kuat. Kiren termasuk sama seperti Meyane masuk kategori generasi milenial $\mathrm{Z}$ yang identik dengan sosial media. Namun dia berbeda dengan temen-teman sebayanya yang sangat penuh filter dengan sosial media. Kiren pribadi yang sedikit tertutup dan pilih-pilih dalam hal berteman. Latar belakang dia sebagai orang asli Jakarta yang sedari kecil sudah diberi privilege oleh orang tua mejadikan dia safety dalam karir. Bahkan jaminan untuk studi S2 pun didapatkanya dari orangtuanya. Tapi dia masih kurang puas dengan apa yang diraihnya di Jakarta sekarang. Dia memimpikan untuk kedepan tinggal di luar negeri yang bisa menjamin semua ekspektasinya dalam karier.

Dia bercerita tentang bagaimana padangan dia dalam karir, Kemudian tentang konsep hijarah yang baru dia jalankan. Kiren hampir satu tahun ini menjalakankan konsep hijarah dengan berjilbab. Dia mempunyai madzab salafi yang sedikit berbeda dengan yang ada di Indonesia. Karena dia melihat dan memakai semua jawaban dengan kasus dalam undang-undang pernikahan. Yang juga ada poin yang mengatur bahwa lakilaki adalah kepala keluarga, sedangkan perempuan hanya pelaksana. Dengan adanya undang-undang ini, dia mengatakan bahwa secara otomatis laki-laki lebih tinggi derajatnya dari pada perempuan. Dia dengan tegas juga megatakan bahwa padangan tersebut itu bukanlah bentuk dari 
budaya patriarki. Dia kekeuh menegaskan lagi dengan alasan kita ini masih Negara Hukum. Jadi kita harus taat dan mengiktui aturan hukum yang berlaku di negeri ini. Ditambah lagi dalam komposisi hukum hak waris, pembagian harta perempuan dan laki-laki jika ada perceraian adalah 1-2 yang artinya laki-laki lebih tinggi.

Berbekal latar belakang hukum, Kiren melihat suatu persoalan terutama dalam karier sangat konservatif. Proporsi hukum positif yang selalu menjadi acuan dalam memandang pesoalan tersebut. Satu sisi dia bicara menginginkan sebuah kesetaraan antara laki-laki dan perempuan. Tapi disisi lain dia juga membenarkan dogma-dogma agama yang dia anut. Seperti secara kodrat bahwa laki-laki harus mapan lebih dari perempuan.

Dia setuju dengan dengan konsep feminisme. Tapi dia juga setuju dengan poligami. Sedangkan dalam catatan Komnas Perempuan kekerasan dalam rumah tangga dan anak-anak terlantar salah satu penyebabnya adalah poligami. Di mana justru karier perempuan tidak berkembang dan tambah termarjinalisasi.

Berikutnya Desi, dia memiliki pribadi yang sangat ambisius dengan posisinya sekarang sebagai sales kordinator. Dia sama sekali belum puas atas pencapaiannya tesebut. Walaupun secara materi dia bilang sudah cukup, bahkan untuk tinggal dia sendiri di apartemen dan bahkan untuk membantu kedua orangtuanya sekarang dia sudah bisa. Target dalam waktu dekatnya adalah ingin menjadi public relations manager di hotel dia bekerja. Upaya untuk ke sana sudah dipersiapakan dengan matang selain studi di public relations. Lewat pendekatan dengan berabagai atasanpun dilakukanya untuk memenhi ambisinya tersebut. Deci termasuk orang yang mulai berkarier dari bawah dimulai dari weters. Dengan kerja keras yang dilakukan, kemudian dia kemudian naik menjadi sales. Sampai sekarang dia udah naik jabatan menjadi sales kordinator di hotel bintang lima di Jakarta.

Pekerjaanya di dunia perhotelan mau tidak mau mendekatkan dia dengan kehidupan malam. Sering kali karena tuntutan pekerjaan dan persaingan yang ketat. Memaksa dia untuk menjaga relations dengan customer dengan ikut kegiatannya di luar kantor. Seperti ikut menemani dinner, ikut clubbing di club malam, sampai pada dia harus ikut minum beralkohol. Ini katanya ada semacam perintah tidak tertulis oleh atasanya untuk melakukan service dengan customer diluar kerja. Dia mengatakan, hal ini lumrah dilakukan mengingat persaingan di dunia hotel yang semakin hari semakin sengit dengan munculnya platform R\&B. Ada bentuk relasi kuasa antara customer dan manager membuat Deci harus ikut dalam pemainan mereka. Termasuk mengikuti kegiatan di luar kantor customer dan aktivitas itu tidak dalam hitungan lembur kerja. Bahkan kantor tidak peduli dengan apapun kegiatan para sales diluar kator dengan customer. Deci pun bercerita pernah sampai diajak liburan ke Turki dengan salah satu customer prioritas hotel tersebut.

Pada narsum Celi, makna bahagia baginya sangat sederhana ketika dia bisa makan apa yang diinginkan di situ dia merasa bahagia. Padangannya tentang karier, Celi lebih suka menekankan pada proses bukan hasilnya. Karier yang dicapainya sekarang sebagai public relations salah satu konsultan besar di jakarta tidak lepas dari proses awalnya yang sangat berliku. Dia mengawali karir lebih dulu berkerja di perusahan tambang di Kalimantan. Pekerjaan yang cukup mapan dari segi penghasilan itu dia tinggalkan dan lebih memilih merantau ke Jakarta demi menggapai impianya. Dia memulai dari dari awal lagi untuk meniti karir seabagi public relations di Jakarta. Beranjak dari latar belakang keluarga yang ibu dan bapaknya yang sudah cerai memaksa dia untuk berjuang sendiri. Dari situ dia belajar untuk mandiri sampai seperti sekarang ini. Selain bekerja di kantor yang sekarang dia juga membuka jasa konsultan personal branding untuk kantor-kantor baru starup di Jakarta. Dia bermain dua kaki dengan perusahan sekarang sepengetahuan bosnya dan anehnya katanya justru dia mendapatkan dukungan penuh dari bosnya sekarang. Sekarang dia merasa puas dengan karir yang diraihnya di kota Jakarta. Dari pada ketika dia masih berkarier di Banjarmasin. Dinamika pekerjaan di kota Jakarta mengasahnya untuk terus berkembang mengasah kemampuannya.

Sosoknya yang friendly membuat dia mudah bergaul dengan siapapun. Dia bercertia bahwa banyak sekali lelaku yang menginginkannya untuk menjadi pacarnya. Sampai pada saat ketika putus seharipun langsung banyak yang sudah menghubunginya untuk mengajak jalan. Di tunjang fisik yang cantik, dari waktu SMP katanya sampai sekarang sudah tidak terhitung beberapa pacarnya. Dia tipikal orang yang pemilih, beberapa kali dia memutuskan pacarnya hanya karena tidak bisa mengimbanginya dalam hal berpikir. Dia sangat hati-hati untuk menentukan laki-laki mana yang kelak akan menjadi suaminya. Dia sabelajar dari pengalaman kedua orangtuanya yang gagal dalam 
membina rumah tangga. Dia mengidamkan sosok yang bisa mendukung dia dalam kariernya kedepan.

Media sosial baginya adalah saran untuk personal brading. Lewat media social dia juga banyak menemukan teman baru bahkan sampai dapat project. Dia tergabung dalam grub-grub penggiat sosial media. Apa yang dia citrakan di sosial media adalah sebagai seorang profesional public relations dan jurnalis. Dia sangat update dengan media sosial bahkan dia mempunyai banyak pengemar di sosial media.

Pada narsum Wenny, yang merupakan pekerja sektor formal yaitu pegawagai negri sipi (PNS). Pekerjaannya sekarang itu merupakan impianya sejak dulu saat masih kuliah di Jogja. Kemudian setelah lulus kuliah dia langsung mengejajar impianya tersebut. Dengan prosesnya yang sangat sulit akhinya dia mampu untuk mendapatkanya. Dia menjadi pegawai negri sipil di salah satu lembaga negara. Perjalanan awal sebagai pegawai negri sipil tidak lah muda seperti yang dibayangkan. Garis komunikasi dari atasan ke bawahan yang tegak lurus dan kaku membuat awalnya dia sulit beradaptasi dengan lingkungan. Ditambah dengan lingkup pekerjaanya yang berhubungan dengan dekat dengan Istana Presiden dengan berbagai kebijakanya. Sempat berkali-kali pekerjanya sebagai seorang analis tidak diapresiasi karena tidak sesuai dengan keinginan dari stakeholder terkait. Sampai-sampai dalam hal kecil saja dia mesti harus dicek dengan detail oleh atasanya. Sempat berkali-kali dia mengalami tindakan tidak meyenangkan oleh lingkungan kantornya. Bahkan dia pernah mengalami pelecehan seksual verbal dengan beberapa atasan terkait. Namun dia tetep bertahan dengan alasan karena pekerjaan pilihan dan backroundnya yang orang dari rantau harus tetap bertahan.

Dalam perjalanya yang penuh dengan tekanan akhinya dia sampai mendapatkan beasiswa untuk melajutkan studi ke Australia selama dua tahun. Lewat proses izin yang sangat alot, bahkan sampai dibuat susah dengan atasanya. Namun akhirnya dia mendapatkan beasiswa tersebut. Mendapat beasiswa itu baginya sebuah mimpi sekaligus hikmah dari berbagai kejadian yang tidak menyenagkan yang pernah dialami selama bekerja. Sepulangnya dari Australia sekarang dengan kebijakan dari pemerintah yang berbeda dengan yang dulu. Dia berharap kejadian-kejadian tidak menyenangkan dalam kariernya tidak terjadi lagi. Jika sampai terjadi dia akan menyiapkan jalan untuk mencoba dengan karir baru sebagai peneliti.

Lalu Rina, dia mengawali karier sebagai seorang model saat dia masih di Samarinda. Dia memulainya sejak kuliah S1 di Samarinda bahkan dia harus bener-bener bisa mengatur waktunya karena di juga masih harus bekerja. Dia sampai pernah bekerja sebagai seorang witers di hotel. Dia mengawali karir sebagai model bener-bener mulai dari nol. Dulu awalnya teman-temanya selalu mengolok-olok dan tidak mau berteman denganya. Dikarenakan karena kondisi rina dan keluarga yang serba kekurangan. Bahkan Dia harus berjibaku sendiri untuk meniti karirnya keluarga hanya cuman bisa mendukung dengan bentuk doa. Di tambah dengan kondisi orangtanya yang sudah bercerai memaksanya untuk benerbener mandiri.

Kemudian pada rina namanya mencuat sejek ia nekat ikut audisi Miss Selebrity di Jogja. Dia nekat pergi ke jogja sendiri, karena termotivasi dalam hidup di usianya yang 23 tahun tapi dia belum melakukan hal-hal besar dalam hidup. Dengan persaingan yang sangat ketat, diringin niat yang kuat akhirnya dia mendapatkan tiket putaran final dan berhak ke Jakarta. Titik balik itulah yang membuat dia semakin yakin untuk total bergelut di dunia model. Setelah mendapatkan tiket grand final dia pergi ke Jakarta. Di situ dia bener-bener diajari tentang tata cara menjadi model profesional. Walaupun dia hanya sampai pada sepuluh besar, tetapi dia sangat bangga akan pencapainya tersebut. Paska dari kontes itu dia sering mendapatkan pemotretan ke luar daerah yang dulunya skup pekerjaanya hanya seputar Samarinda. Dari situ dia sering mendapatkan tawaran pemotretan sampai ke Bali bahakan daerah - daerah lainya. Namanyapun semakin bersinar di kalimantan khususnya di daerah samarinda karena dia perwakilan satusatunya dari provinsi tersebut.

Awalnya dia ke Jakarta untuk melanjutkan studi yang dijalaninya pulang pergi dari Samarinda ke Jakarta. Setiap jumat malam dia harus sudah berada di Jakarta. Mulany, dia enggan melepaskan pekerjaanya di Samarinda, karena dia sudah mempunyai nama besar di kota Samarinda. Job pemotretan sebagai seorang model tidak pernah berhenti di kota tersebut. Tapi kini dia justrul mantap untuk meniti karir sebagai model di Jakarta. Awal di Jakarta dia mengira akan susah beradaptasi dengan teman-teman baru, Tapi justrul dengan teman-teman baru itu, dia banyak dapat dukungan dan support system baru. 
Kini dia telah kurang lebih 2 tahun di Jakarta. Jobnya tidak hanya sekedar pemoteretan namun dia juga mendapatkan job-job untuk mengisi acara event.

Dunia permodelan yang erat dengan dunia gemerlap membuat dia harus pintar dalam menjaga diri. Tak jarang di lingkungan dia bekerja erat kaitanya dengan anggapan miring. Bahkan dia pernah mengalami pelecehan seksual pada suatu ketika mengisi sebuah acara di Balikpapan dari situ ada seorang pemenang acara yang memaksa ingin memasukan uang ke dalam pakainya tepatnya ke dalam dadanya. Dia pernah juga ketika dalam sebuah wawancara pekerjaan ditanya tentang statusnya yang masih perawan atau belum. Bahkan ketika dia dinyatakan diterima, dia harus mau diajak tidur bersama dengan bosnya. Kini dia mempunyai kekasih yang baik dan bertanggung jawab yang mencukupi kehidupanya selain sebagai model. Dengan memberikan modal pinjaman untuk usaha.

Media sosial baginya sangat krusial untuk personal branding dirinya sebagai seorang model. Dia ingin mencitrakan bahwa dia adalah model papan atas yang kelas. Setiap kali di share tentan foto di Istagram harus terlihat kelas dan mewah. Karena dari instagram dia banyak mendapatkan banyak endorsement dan job pemotretan. Dia pernah mendapatkan job untuk foto ke Malaysia hanya dengan lewat media social awalnya.

Pada narsum Fiki, makna bahagia baginya dalam karir jika dia bisa turun menyapa warganya atau konstituennya. Profesi Fiki sekarang adalah total sebagai seorang politisi. Dia tahun ini maju sebagai calon anggota legislatif DPR RI Dapil DKI Jakarta I dengan daerah pemilihan Jakarta Kota, Jakarta Selatan dan Luar Negri. Fiki maju sebagai sebagai caleg dari Partai Garuda. Partai baru yang tergolong masih membutuhkan banyak suara untuk lolos parlementary threshold. Sebelum berlabuh di Partai baru itu, dia lebih dulu aktif di Tidar Jakarta sayap Partai Gerindra. Isu yang akan di bawanya ke Parlemen jika menanga adalah tentang kepemudaan dan olahraga. Fiki sendiri adalah mantan Atlit Bisbool Jakarta. Selain itu dia juga akan membangiktkan kembali perkumpulan di tyap keluranhan yang dianggapnya tidak hidup lagi dan terkikis oleh zaman.

Fiki meninggalkan aktivitasnya dan meningalkan pergaulan sosialitanya untuk total menjadi politisi. Awalnya fiki seorang yang suka hidup hedonism (glamour) dan hidup mewah seperti clubing, suka konsumtif dengan barang- barang brandit, sampai kecanduan alcohol pernah ia jalani. Dia mengaku bahwa dia seorang yang liberal suka dengan kebebasan dalam hidup dan berkiblat fasion style Inggris.

Model kampanye yang dijalankan fiki, lebih kepada door to door dengan menyapa warga Jakarta. Dengan menyapa warga dia ingin tahu apa sebenarnya yang menjadi permasalah warganya saat ini. Dengan menyapa warga dia juga berharap lebih dekat dan dikenal warga. Namun yang menjadi pertanyaan dan catatan di tengah kota Jakarta yang dengan kategori pemilih kritis dan melek terhadap media sosial, dia sama sekali tidak mengunakan media sosial untuk kampanye politiknya. Dia beranggapan bahwa dengan media sosial hanya dijadikan seabagai alat pencitraan oleh politisi-politisi gadungan yang ujungya korupsi katanya. Dia juga berpesan untuk generasi muda di bawahnya jangan takut untuk terjun kedunia politik khususnya perempuan. Sekarang waktunya laki-laki dan perempuan setara. Ini sangat penting baginya karena perwakilan perempuan di DPR untuk anggota dewan dari perempuan tidak mencapi $30 \%$ dari total anggota. Jika perwakilan perempuan masih kurang bagimana keadilan gender dapat ditegakan dalam sistem politik yang masih patriarki menurutnya. Dia menghimbau bahwa perempuan jangan takut kalau terjun ke dunia politik sekarang dapat perlindungan dari pemerintah. Kekerasan seksual dalam bentuk apapun sudah terminimalisir dengan aturan tersebut. Dia mengaku juga sebagai seorang yang feminis liberal yang menjunjung tinggi kesetaran laki-laki dan perempuan.

Pada narsum Vania, bahagia dalam karir yang dijalani ketika dia bisa membagi ilmu apa yang dia miliki terhadap orang lain. Ketika dia bisa menulis tanpa adanya rasa tuntutan dan tekanaan dari pihak manapun di situ dia juga merasa bahagia. Profesi vania sekarang adalah sebagai seorang dosen dan juga aktif sebagai aktivis perempuan di Komnas Perempuan. Sejak kecil dia bercerita selalu tertarik dengan profesi dosen dan aktivis perempuan. Kepedulian tentang isu-isu perempuan sejak kecil membawanya aktif dan terlibat beberapa organisasi sejak di kampus. Dia penah tergabung dengan organisasi intra kampus seperti BEM dan organisasi ekstra kampus Ikatan Mahasiswa Muhamadiyah (IMM). Jabatan terakhir yang diembanya bahkan sampai pada ketua IMM cabang Ciputat. Saat di kampus, dia orang yang sangat aktif dalam kajian-kajian diskusi ilmiah. Dia sering menjadi pemateri kecil 
dalam diskusi-diskusinya dengan teman-temannya di kampus.

Kehidupanya selalu lekat dengan politik namun sampai detik ini ia enggan terjun langsung ke dunia politik. Dia lebih suka dengan bentuk gerakan aktivisme. Idealisme sampai sekarang masih ia gengam betul paska lulus kuliah. Dia sangat familiar dengan konsep feminisme. Di antara beberapa aliran feminisme dia paling cocok dengan feminisme sosialisme. Dia tidak suka dengan pandangan liberal yang membebaskan otoritas individu penuh, namun tidak mempedulikan masyarakat kecil baginya feminisme liberal selalu berjarak dengan masyrakat. Dia tidak cocok dengan sistem ekonomi kapitalisme yang diangapnya memperlemah peran negara dan bergantung dengan pasar dalam hal ini swasta. Masyarakat kita khususnya kalangan bawah belum siap akan hal itu, dengan ditambah tingkat literasi yang rendah, baginya ini akan menimbulkan persoalan ketidakadilan gender dalam karier khususnya perempuan.

Media baginya bukan hanya untuk ajang berjejaring, tapi juga sebagai lahan aktualiasi dirinya. Dia Sering menuangkan ide-ide dan gagasan-gagasanya di dalam media sosial. Selain itu media juga ajang atau saran untuk mengkampanyekan kesadaran kolektif tentang ketidakadilan gender dalam karir. Selain gerakan feminisme yang harus ditingkatan wacanaya di sosial media. Feminisme juga harus merambah kedalam gerakan sosial di masyarakat. Itu akan berimbas langsung dengan apa yang menjadi keresahan masyarakat selama ini. Dia dan temantemannya bahkan sering melakukan kajian-kajian riset tentang feminisme dalam studi jurnal. Ini dilakukanya karena untuk selain untuk mengasah studi literasinya juga dalam rangka memenuhi panggilan jiwanya seabagai seorang dosen muda dan seorang aktivis gender.

Dari paparan diatas adapun perbedaan yang mecolok antara perempuan karir yang berasal dari luar Jakarta pendatang dan yang perempuan karier asli Jakarta dalam memadang karir. Perempuan karir pendatang secara mental lebih bagus dibandingkan dengan perempuan karier di Jakarta dalam ketahanan tekanan dunia kerja. Perempuan karir pendatang menemukan jawaban atas karier yang di jalani di kota Jakarta dibanding kota asalnya. Sedangkan perempuan asli Jakarta secara mental tidak terlalu bagus dengan pekerjaan yang tingkat tekanan tinggi. Kemudian secara karir perempuan asli Jakarta memandang kota Jakarta ini bukanlah tujuan dari karirnya. Mereka lebih memimpikan bekerja di luar negri seperti di Australia, Eropa dan Amerika.

Dua Narsum wanita karir Rina dan Celi dalam memandang karir dan pernikahan beda dengan narusm lainya. Mereka berdua berlatar belakang keluarga yang bercerai sejak mereka masih di bangku SMA. Tentu hal ini membuatnya harus lebih keras dalam memperoleh karier sampai detik ini. Karena dukungan keluarga terhadap mereka tidak sepenuhnya dia dapat. Bahkan Rina hari ini harus membantu untuk menghidupi ibunya.

\section{Kesimpulan}

Globalisasi dan siwtem kapitalisme sangat memengaruhi pandagan karier perempuan hari ini. Semua orang dipaksa bergegas dari satu pencapaian ke pencapaian lainya. Semua orang dipaksa berkompetisi satu sama lain dalam karier serta terus berjarak dengan realitas alsinya. Celakanya, karier ideal yang diidamkan dan yang dikonstruksikan oleh media adalah bagian agenda setting kapitalisme global untuk tetap menancapkan dominasinya di negara ketiga seperti Indonesia. Kita tidak punya konsep murni dalam karir yang ada kita dicetak sebagai komoditi dalam produksi global.

Jakarta hari ini masih menjadi impian sebagian perempuan dalam meniti kariernya. Jakarta menawarkan kesempatan bagi perempuan karier untuk mengeksplor dirinya lebih dalam karier. Akses informasi dan jejaring yang tidak berbatas membuat Jakarta seolah disneyland Indonesia. Generasi milenial ini adalah generasi yang sudah akrab dengan sosial media. Dalam memandang karier media sosial adalah salah satu rujukan untuk menentukan di mana kelas sosial akan didapatkan dalam karier. Ketika hilang batasan dalam memandang karier, apa yang dilihat di dunia nyata dan sosial media. Seketika itu membuat hilangnya ruang batasan antara realitas nyata dan impian virtual itu nampak sulit untuk di bedakan. Kesadaran palsu itu membuat hyperrealitas dalam karier khususnya bagi perempuan hari ini.

Sementara itu semua wanita karier yang peneliti teliti sangat beragam dalam memaknai kebahagian dalam hidup khususnya tentang karier. Konsep kebahagiaan perempuan karir di abad 21 adalah buah hasil dari konstruksi perkembangan teknologi informasi dan komunikasi. Efek budaya modern kontemporer sangat nyata dalam menggubah perilaku 
perempuan karier hari ini dalam memaknai sebuah pekerjaan.

Tapi yang menjadi catatan sekaligus pertanyaan kelanjutan dari penelitian ini yaitu ketika semua pekerjaan sudah terotomasi apakah masih ada kebahagiaan dalam karir. Seiring berjalannya waktu dengan era revolusi industri 4.0 sekarang ini. Dalam penelitian ternyata teknologi untuk membuat kehidupan lebih bahagia telah ditemukan "editing genome" ketika kebahagian sendiri sudah bisa diedit secara terotomasi ke dalam bilogi tubuh kita. Kedepan tentunya akan banyak pertanyaan-pertanyan yang akan mengejutkan terutama tentang makna bahagia bagi karier.

\section{References}

Baudrillard, J. (2006). Ekstasi Komunikasi. Yogyakarta: Kreasi Wacana.

Bollotin, S. (1982). Voices from the Post-feminist Generation. New York Times Magazine. https://www.nytimes.com/1982/10/17/magazine/ voices-from-the-post-feminist-generation.html

Engels, F. (2007). Tentang Das Kapital Karl Marx. E. Cahyono (Ed.) Terjemahan: Oey Hay Djoen. Oey’s Renaissance.
Harari, Y. N. (2017). Sapiens. Ciputat: Pustaka Alvabet.

Harari, Y. N. (2018). Homo Deus: Masa Depan Umat Manusia. Jakarta: PT Pustaka Alvabet.

Lubis, A. Y. (2014). Postmodernisme Teori dan Metode. Jakarta: PT Raja Grafindo Persada.

Meiliana, S. (2016). Sociology of Literature \& Feminist Sociological Theory. Tangerang: Pustaka Mandiri.

Neuman, W. L. (2013). Metodologi penelitian sosial: pendekatan kualitatif dan kuantitatif. Jakarta: Indeks.

Nguyen, T. (2013). From SlutWalks to SuicideGirls: Feminist Resistance in the Third Wave and Postfeminist Era. WSQ: Women's Studies Quarterly, 41(3-4), 157-172. https://doi.org/10.1353/wsq.2013.0102

Ritzer, G., \& Goodman, D. J. (2007). Teori Sosiologi Modern. Jakarta: Kencana Predana Media.

Showden, C. R. (2009). What's Political about the New Feminisms? Frontiers: A Journal of Women Studies, 30(2), 166-198. http://www.jstor.org/stable/40388740

Statistik, B. P. (2017). Indeks Kebahagiaan 2017. https://www.bps.go.id/publication/2017/12/05/1 f99cefd596c449b93405fcd/indeks-kebahagiaan2017.html

Walter, N. (1999). The New Feminism. London: Virago Press. 